УДК 378.017:[379.81:373]

DOI:

Ірина Резніченко, кандидат педагогічних наук, старший викладач кафедри виховних технологій та педагогічної творчості Уманського державного педагогічного університету імені Павла Тичини

\title{
ФОРМУВАННЯ ДИСЦИПЛІНОВАНОСТІ МОЛОДШИХ ШКОЛЯРІВ ПІД ЧАС ОСВІТНЬОГО ПРОЦЕСУ
}

У статті розглядається актуальна на сьогодні тема формування дисциплінованості молодиих иколярів під час освітнього процесу. 3'ясовано сутність дисииплінованості, специфіка формування изієі інтегрованої якості в молодшому шкільному віці. Визначено, щуо молодиий шкільний вік є синзитивним періодом для формування свідомої дисцииліни. Обтрунтовано педагогічні умови формування дисциплінованості молодших иколярів під час освітнього процесу, які об’єднано в три групи - організаційно-методичні, психолого-педагогічні, технологічні.

Ключові слова: дисичплінованість; икільна дисичиліна; свідома дисичиліна; сенситивний період; молодиий шкільний вік; освітній процес; умови формування дисичилінованості.

Jim. 9.

Iryna Reznichenko, Ph.D.(Pedagogy), Senior Lecturer of the Education Technologies and Pedagogic Creativity Department Uman Pavlo Tychyna State Pedagogical University

\section{FORMATION OF DISCIPLINATION OF YOUNG SCHOOLCHILDREN UNDER THE EDUCATIONAL PROCESS}

The article is dealt with the current issue of the formation of discipline of junior schoolchildren in the educational process. Democratization of the school environment significantly influenced the behavior of students. The pupils became more active, independent and initiative, free in expressing their thoughts, in actions and in no way inclined to unconditionally follow the rules of discipline. These circumstances cause serious concern for teachers who understand that these are positive changes, however, they can cause significant difficulties in the educational process, reduce its effectiveness and negatively affect the level of education and parenting of schoolchildren. In these conditions, the study and rethinking of the problem of school discipline, the study of the process of formation of discipline and the identification of pedagogical conditions that ensure the effectiveness of the development of this quality in schoolchildren becomes significant. found out

The essence of discipline, specificity of the formation of this integrated quality at the junior school age is

The pedagogical conditions of the formation of the discipline of junior schoolchildren during the educational process, which are grouped into three groups - organizational-methodical, psychological, pedagogical, technological, are grounded.

We understand the organizational and methodological conditions as interconnected prerequisites that ensure the purposeful management of the process of forming the discipline of junior pupils. The system of organizational and methodological conditions is aimed at the planning, organization, selection of forms and methods for the formation of this quality.

Psychological and pedagogical conditions are intended to ensure the development of positive motivation for the educational activities; implementation of the public norms and the rules of conduct; the value attitude to discipline and discipline of junior pupils.

We understand the technological conditions as a certain set of circumstances and methods that ensure the effectiveness of the formation of discipline of junior students in the educational process. We refer to them specifically designed and organized forms of work with children, teachers and parents aimed at the effectiveness of the research process.

Keywords: the discipline; school discipline; conscious discipline; sensory period; junior school age; an educational process; conditions for the formation of discipline.

$\Pi$ остановка проблеми. На сьогодні життя вимагає від людини високої дисципліни і виконавської чіткості. Особливу роль у їх формуванні належить освітньому процесу школи. Адже, саме в школі дитина робить перші кроки у цьому напрямі. Шкільна дисципліна $є$ умовою нормальної освітньої діяльності школи. Цілком очевидно, що за відсутності дисципліни не можна провести на належному рівні ні уроку, ні виховного заходу, ні 


\section{ФОРМУВАННЯ ДИСЦИПЛІНОВАНОСТІ МОЛОДШИХ ШКОЛЯРІВ ПІДЧАС ОСВІТНЬОГО ПРОЦЕСУ}

будь-якої іншої справи. Вона є водночас і засобом виховання школярів. Дисципліна сприяє підвищенню виховної ефективності діяльності учнів, дає змогу обмежувати, гальмувати нерозважливі дії та вчинки окремих школярів.

Педагоги-класики(П.П.Блонський,Л.С.Виготський, А.С. Макаренко, В.О. Сухомлинський, С.Т. Шацький та ін.) підкреслювали важливість виховання у дітей дисципліни, що було обумовлено, головним чином, практичними потребами.

У сучасний період ця проблема не втратила свою актуальність, а лише загострилася. Демократизація шкільного середовища істотно вплинула на поведінку учнів. Школярі стали більш активні, самостійні й ініціативні, вільні у висловлюванні своєї думки, у вчинках і аж ніяк не схильні до безумовного наслідування правил дисципліни. Дані обставини викликають серйозну заклопотаність вчителів, які розуміють, що це позитивні зміни, проте, вони можуть викликати суттєві труднощі у освітньому процесі, знизити його результативність і негативно вплинути на рівень освіченості і вихованості школярів. У цих умовах значущості набуває вивчення i переосмислення проблеми шкільної дисципліни, дослідження процесуформування дисциплінованості і виявлення педагогічних умов, що забезпечують ефективність розвитку цієї якості у школярів.

Сензитивним періодом формування дисциплінованості виступає молодший шкільний вік, оскільки саме тут з'являється найважливіше новоутворення, що робить істотний вплив на формування дисциплінованості - довільність; закладаються основи моральності; йде свідоме освоєння соціального середовища і способів діяльності (М.М. Безруких, М.Н. Волокітіна, Л.А. Висотіна, Т.Я. Довга, В.В. Зіньківський, А.А. Люблінська, А.В. Мудрик, Н.Ф. Тализіна, Д.І. Фельдштейн, С.Г. Якобсон та ін.).

Проблемою формування дисциплінованості школярів займаються дослідники у загальпедагогічному (В.С. Гмурман, Т.Д. Лейченко, Н.С. Лукін, I.C. Марєнко, Е.I. Моносзон, Г.І. Щукіна та ін.) і психологічному аспектах (Б.А. Бенедиктом, В.А. Кругсцкій, Л.В. Рувинський, 3.С. Сиріщева та ін.).

Незважаючи на те, що в педагогічній науціє певні передумови для вирішення досліджуваної проблеми, багато аспектів формування дисциплінованості молодших школярів в освітньому процесі, 3 урахуванням несталих соціальних відносин залишаються ще недостатньо розробленими.

Мета статті полягає в обгрунтуванні педагогічних умов формування дисциплінованості молодших школярів під час освітнього процесу.
Виклад основного матеріалу дослідження. Однією із морально-правових якостей особистості є дисципліна (від лат. - вчення, виховання, розклад) як певний порядок, що відповідає нормам, правам i моралі суспільства, визначається суспільними відносинами та слугує для їх підтримки $[5,199]$. Дисципліна - якісна характеристика порядку, організованості певної спільноти, сфери життедіяльності людей, яка відображає відповідність їхньої поведінки загальноприйнятим нормам права і моралі $[6,88]$.

У педагогіці розрізняють дві форми дисципліни: свідому й несвідому або внутрішню і зовнішню. Свідома (внутрішня) дисципліна спирається на усвідомлення людиною своїх обов'язків і розуміння тих правил, яким вона підкорюється. За такої дисципліни створюється особисте усвідомлення своєї правоти і сили, оскільки, підкорюючись певним правилам, людина підкорюється сама собі, своєму сумлінню й свідомості. Розробивши теорію дисципліни, А. Макаренко зазначав, що вона потрібна для того, щоб кожна людина свідомо виховувала в собі вміння переборювати перешкоди, формувала впевненість у своїх силах і правоті, була переконана в необхідності та корисності своєї діяльності для суспільства [4, 334]. Несвідома (зовнішня) дисципліна базується на почутті остраху і кари за невиконання обов' язків або на бажанні одержати схвалення, винагороду за іiі виконання. У цьому випадку відсутнє усвідомлення доцільності правил, що регулюють діяльність [2, 366].

На думку Г. Ващенка, саме свідома дисципліна тісно пов'язана із самодисципліною, а точніше спирається на неї, а також передбачає формування такої риси характеру, як дисциплінованість, почуття обов'язку і відповідальність. Самодисципліна, на думку педагога, - це організованість людини в своєму особистому житті й праці, що вимагає підкорення своєї поведінки певному високому ідеалу $[2,366]$.

У педагогічній системі В. Сухомлинського основою свідомої дисципліни учнів $є$ відповідальність, яка органічно поєднує громадянськість і совість. На думку педагога, саме “совість” є тим центральним угворенням у свідомості дитини, тим внугрішнім механізмом, що детермінує напрям становлення індивіда як особистості [7, 25].

Свідома дисципліна - інтегративна властивість особистості, закономірно вінчає весь процес ії формування. А.С. Макаренко підкреслював, що дисципліна у нас $є$ явище моральне і політичне, порушник ії вимог по суті виступає проти інтересів колективу, суспільства і своїх власних. 


\section{ФОРМУВАННЯ ДИСЦИПЛІНОВАНОСТІ МОЛОДШИХ ШКОЛЯРІВ ПІДЧАС ОСВІТНЬОГО ПРОЦЕСУ}

Наукова педагогіка виводить ідеї свідомої дисципліни $з$ органічного поєднання інтересів особистості і суспільства, свідомого ставлення до праці і дбайливого - до суспільного надбання. Свідома дисципліна як суспільне явище визначається світоглядом, цивільними переконаннями. Вона припускає цілеспрямоване зосередження уваги, волі, всіх інтелектуальнотворчих здібностей і фізичних сил на вирішенні завдань оновлення. Свідома особистість характеризується проявом активності та ініціативи, непримиренною боротьбою з застоєм, труднощами і недоліками. Свідома дисципліна $\epsilon$ дисципліна товариська, усілякої довіри, ініціативи та солідарності в боротьбі. Вона являє собою найкращу форму досягнення господарських i політичних цілей $[8,53]$.

Характер дисципліни всього суспільства, як відомо, відображає шкільна дисципліна, у якій передбачено, щоб учні дотримувалися правил поведінки у школі та за її межами, чітко й організовано виконували свої обов'язки, підкорялися суспільному обов'язку [5, 349]. Показниками високого рівня дисципліни $є$ розуміння учнями необхідності дотримання ii y школі, громадських місцях, в особистій поведінці; готовність і потреба у виконанні загальноприйнятих норм та правил дисципліни праці, навчання, вільного часу; самоконтроль у поведінці; боротьба з порушниками дисципліни у школі та за її межами.

Принципи особистісно-орієнтованого підходу (принцип самоактуалізації, індивідуальності, суб'єктності, принцип вибору, творчості і успіху, довіри і підтримки) і його технологічна складова мають важливе значення при розробці педагогічних умов, що сприяють ефективному формуванню дисциплінованості молодших школярів в освітньому процесі.

Аналіз психолого-педагогічної літератури засвідчив, що існують різні підходи до визначення сутності категорії “педагогічні умови”.

У тлумачному словнику української мови зазначається, що умова - це “необхідна обставина, яка робить можливим здійснення, створення, угворення чого не будь або сприяє чомусь” [3, 632].

Виходячи 3 цього, педагогічні умови можна розглядати як комплекс взаємопов'язаних заходів освітнього процесу, що здійснюються з усіма суб' єктами педагогічного процесу. Н. М. Боритко визначає педагогічні умови як зовнішнє обставина, фактор, що робить істотний вплив на перебіг педагогічного процесу, в тій чи іншій мірі свідомо сконструйований педагогом, який передбачає, але не гарантує певний результат процесу $[1,36]$.
Під педагогічними умовами в нашому дослідженні ми розуміємо комплекс взаємопов' язаних факторів освітнього процесу, що роблять істотний вплив на ефективність формування дисциплінованості молодших школярів. Умови - це те, що необхідно враховувати і створювати в якості підтримуючого фону процесу формування дисциплінованості.

К.А. Нефедова, Т.І. Шамова виділяють чотири групи умов навчально-виховного процесу: навчально-матеріальні, шкільно-гігієнічні, морально-психологічні та етичні $[9,56]$. Аналіз умов, що входять до кожної з цих груп дозволив нам виявити можливості їх використання в процесі формування дисциплінованості ізробити відповідні висновки. Виділені педагогічні умови можуть зробити істотний вплив на формування досліджуваної якості.

Однак, на наш погляд, такий підхід до розробки педагогічних умов, спрямованих на формування дисциплінованості молодших школярів відображає більшою мірою лише один аспект проблеми - формування дисциплінованості в процесі навчання. Для нашого дослідження велике значення має усвідомлення того, що формування дисциплінованості відбувається в цілісному освітньому процесі, в організації всіх видів дитячої діяльності: навчальної, трудової, громадської, пізнавальної, ігровий, творчої.

Сутність дисциплінованості, специфіка формування даної інтегрованої якості в молодшому шкільному віці, а також закономірності і можливості освітнього процесу визначили вибір педагогічних умов, які ми об'єднали в три групи - організаційно-методичні, психолого-педагогічні, технологічні.

Організаційно-методичні умови ми розуміємо як взаємопов' язані передумови, що забезпечують цілеспрямоване управління процесом формування дисциплінованості молодших школярів. Система організаційно-методичних умов спрямована на планування, організацію, вибір форм і методів формування даної якості. До організаційнометодичних умов ми відносимо:

- створення сприятливого психологічного клімату, який сприяє формуванню дисциплінованості молодших школярів в освітньому процесі;

- дотримання санітарно-гігієнічних норм навчальних занять: достатня освітленість, провітрювання класу, використання фізкульт хвилинок і т.д .;

- доцільне і розумне проведення перерв як часу найбільш сприятливого для самоконтролю та саморегуляції поведінки школярів; 


\section{ФОРМУВАННЯ ДИСЦИПЛНОВАНОСТІ МОЛОДШИХ ШКОЛЯРІВ ПІДЧАС ОСВІТНЬОГО ПРОЦЕСУ}

- встановлення режиму роботи школи як внутрішнього розпорядку, який встановлює точний час навчальних занять і позакласної роботи; контроль за встановленим режимом дня з боку педагогів і батьків, що дозволяє формувати у молодших школярів необхідні звички і навички поведінки;

- створення методичного забезпечення процесуформування дисциплінованості молодших школярів;

- забезпечення взаємодії сім'ї і школи в процесі формування дисциплінованості молодших школярів;

- єдність вимог педагогів до учнів, що виражається в єдності поглядів на мету виховання школярів, єдності підходу до учнів у вимогах, в оцінці їх поведінки, у взаєминах з ними.

Психолого-педагогічні умови покликані забезпечити розвиток позитивної мотивації до освітньої діяльності; виконання громадських норм і правил поведінки; ціннісного ставлення до дисципліни і дисциплінованості у молодших школярів. У зв'язку з цим до педагогічних умов цієї групи можна віднести наступні:

- вивчення особистості школяра, що дозволяє 3'ясувати ступінь сформованих найбільш важливих рис особистості, а також умінь i навичок, які активно впливають на формування дисциплінованості;

- врахування особливостей розвитку дітей молодшого шкільного віку в освітньому процесі (властивості нервової системи, особливості характеру, пам'яті, сприйняття, рівень розвитку уваги; інтереси школярів, їх оточення, проведення дозвілля, статус у класному колективі і т.д.);

- спрямованість на формування позитивного ставлення до навчально-виховної діяльності, уявлень про норми моральності, з метою формування інтересу до суспільних цінностей;

- дотримання наступності у роботі педагогів;

- високий рівень сформованості особистісних якостей вчителя, які найбільш сприятливо впливають на дисциплінованість молодших школярів (глибоке знання предмета, вміння захопити своїм предметом; високий загальний рівень культури вчителя; шанобливе ставлення до школяра, розуміння його, співпереживання з ним за його успіхи і невдачі; вимогливість до учнів, що поєднується 3 доброзичливістю; відповідальність і дисциплінованість самого вчителя; об'єктивність, справедливість в оцінці знань і поведінки; терпіння, витримка вчителя, культура зовнішнього вигляду вчителя), авторитет учителя;

- встановлення демократичного стилю спілкування учителя з учнями, що дозволяє розвивати у школярів почуття власної гідності, формувати дисциплінованість;

- використання можливостей класного колективу у формуванні дисциплінованості молодших школярів (знання закономірностей розвитку дитячого колективу, вивчення реального стану конкретного колективу).

Технологічні умови ми розуміємо як певну сукупність обставин і методів, що забезпечують ефективність формування дисциплінованості молодших школярів в освітньому процесі. До них ми відносимо спеціально розроблені і організовані форми роботи 3 дітьми, педагогами та батьками (заняття, тренінги, класні години, педагогічні тренінги, круглі столи тощо), спрямовані на ефективність досліджуваного процесу.

Вивчивши психолого-педагогічну літературу, виділивши три групи педагогічних умов (організаційно-методичні, психолого-педагогічні, технологічні) і проаналізувавши практичний досвід роботи, ми припустили, що для ефективного формування дисциплінованості молодших школярів в освітньому процесі необхідний комплекс педагогічних умов, що включає в себе:

- готовність педагогів до реалізації різноманітних форм і методів формування дисциплінованості молодших школярів в освітньому процесі;

- методичне забезпечення процесу формування дисциплінованості молодших школярів;

- забезпечення взаємодії сім'ї і школи в процесі формування дисциплінованості молодших школярів через батьківські збори, круглі столи, тренінги та інші форми роботи з батьками, що сприяють підвищенню ефективності формування дисциплінованості молодших школярів.

Висновки і перспективи подальших досліджень. Таким чином, лише за дотриманням виділеного комплексу педагогічних умов, на нашу думку, можливе формування свідомої дисципліни молодших школярів під час освітнього процесу.

Дослідження відкриває широкі перспективи для подальшої роботи у цьому напрямку, що передбачає постановку нових актуальних завдань, які полягають:

- увивченні шляхів формування дисциплінованості як інтегративної якості дітей середнього і старшого шкільного віку, забезпечуючи тим самим взаємозв'язок декількох ступенів освіти;

- у вивченні залежності рівня сформованості дисциплінованості від рівня розвитку дитячого колективу;

- у виявленні найбільш оптимального стилю педагогічного спілкування для створення 
належних умов для формування дисциплінованості школярів.

\section{ЛІТЕРАТУРА}

1. Божович Л.І. Проблеми формування особистості. Вибрані психологічні праці. / за ред. Д.І. Фельдштейна. К.: Ін-т практ, психології; Воронеж: НВО “МОДЕК”, 1995. 349 с.

2. Ващенко Г. Виховання волі і характеру : підручник для педагогів. К.: Школяр, 1999. 385 с.

3. Гончаренко С. Український педагогічний словник. К. : Либідь, 1997. 376 с.

4. Макаренко А. С. Понятие дисциплины в общей системе воспитания. Педагогические сочинения : в 8-ми т. К. : Радянська школа, 1976. Т. 1. С. 349.

5. Родинно-сімейна енциклопедія / авт. кол.: В.М. Благінін, Н. І.Бєлкіна та ін.; за заг. ред. Ф. С. Арвата та ін. К.: Богдана, 1996. 438 с.

6. Словарь-справочник по педагогике / авт.сост. В. А. Мижериков; под общ. ред. П. И. Пидкасистого. М.: ТЦ Сфера, 2004. 448 с.

7. Сухомлинський В. О. Вправляння - один 3 методів виховання свідомої дисципліни. Вибрані твори: у 5-ти т. К.: Радянська школа, 1977. T. 5. C. 21-29.

8. Хоружа Л. Формуємо культуру поведінки молодших школярів. Початкова школа. №2. 2007. C. $52-57$.

9. Шамова Т. І., Нефедова К. А. Виховання свідомої дисципліни школярів в процесі навчання. М.: Педагогіка, 1985. 104 с.

\section{REFERENCES}

1. Bozhovych, L.I. (1995). Problemy formuvannia osobystosti [Problems of personality formation]. Kyiv: Institute of practical psychology, 349 p. [in Ukrainian].

2. Vashchenko, H. (1999). Vykhovannia voli $i$ kharakteru [Education of the will and character]. Kyiv: Shkoliar, 385 p. [in Ukrainian].

3. Honcharenko, S. (1997). Ukrainskyi pedahohichnyi slovnyk[UkrainianPedagogical Dictionary]. Kyiv: Lybid, 376 p. [in Ukrainian].

4. Makarenko, A. S. (1976). Poniatye dystsypliny $\mathrm{v}$ obshchei systeme vospytanyia [Concept of discipline in the general system of education]. Kyiv: Radianska shkola, p.349. [in Ukrainian].

5. Blahinin, V.M. \& Bielkina, N. I. (1996). Rodynno-simeina entsyklopediia [Family Encyclopedia]. Kyiv: Bogdan, 438 p. [in Ukrainian].

6. Myzherykov, V. A. (2004). Slovar-spravochnyk po pedahohyke [Dictionary of pedagogy]. Moscow: Sphere, 448 p. [in Russian].

7. Sukhomlynskyi, V. O. (1977). Vpravliannia-odyn z metodiv vykhovannia svidomoi dystsypliny [Exercise is one of the methods of educating a conscious discipline]. Kyiv: Radianska shkola, pp.21-29. [in Ukrainian].

8. Khoruzha, L. (2007). Formuiemo kulturu povedinky molodshykh shkoliariv [We form a culture of behavior for junior pupils]. Pochatkova shkola Publ., Vol, pp.52-57. [in Ukrainian].

9. Shamova, T. I. (1985). Vykhovannia svidomoi dystsypliny shkoliariv $v$ protsesi navchannia [Education of conscious discipline of students in the process oflearning]. Moscow: Pedagogy, 104 p. [in Ukrainian].

Стаття надійшла до редакції 13.02.2019

\section{G58089c2058080}

"Жобоб дитина була палқо заиікавлена навчанням, ій необхіде багате, різноманітне, приваблююче, інтелектуальне життя".

Василь Сухомлинський

уқраїнський педагог

“Виховання є мистеитвом, використання якого зростатиме протягом багатьох поколінь".

Іммануйл Кант

німецький білособ

"Суть виховання полягає саме в тому, що старше поқоління передає свій досвід, свою пристрасть, свої переконання молодшому поқолінню”.

Антон Макаренко педагог

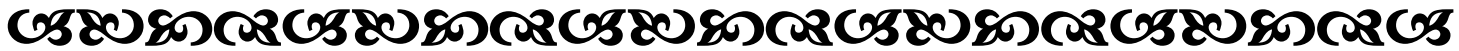

